城市轨道交通综合监控系统（Integrated Supervisory Control System，英文缩写 “ISCS”) 是基于城市管理系 统多样化发展下形成的一种以系统集成 (电力监控系统、环境监控系统、火灾报警系统、道路交通安全管理系统等) 监督与管控为宗旨的综合型控制系统 (如图 1 所示) ${ }^{[1]}$ 。它能够将分散且孤立的系统有机结合, 实现系统互联互通, 以 提升系统间的信息共享水平，满足城市线网运营精细化管理、规模化发展、统一化管理需求，从而提升城市轨道交通 服务水平，推进城市轨道交通的自动化、智能化进程。

因此，城市轨道交通综合监控系统平台设计需满足如下基本功能需求:（1）各类检测信息的自动化采集与集约化管 控;（2）支持分层分布式结构与异构环境，具备各子系统运行状态远程监控与一体化协调能力;（3）根据时间表预设进 行相应设备运行状态自动化控制;（4）历史数据记录、存储与查询;（5）方余设备自动化切换;（6）核心数据备份与恢 复;（7）故障自动识别、诊断与报警;（8）系统管理权限控制与系统通信安全预防；(9）可视化显示与人机互动。

\title{
2 城市轨道交通综合监控系统平台设计技术分析
}

\section{1 综合监控系统结构}

基于城市轨道交通综合监控系统平台设计基本功能需求分析, 可知城市轨道交通综合监控系统的本质在于实现城 市轨道交通各专业系统统一管控。因此, 系统在保留各子系统现场数据采集与及控制设备、操作员（调度员）工作站 的基础上, 将数据服务器、通信设备、显示设备等合并, 使综合监控系统更具学习、操作、维修、管理简便性（图 2)。

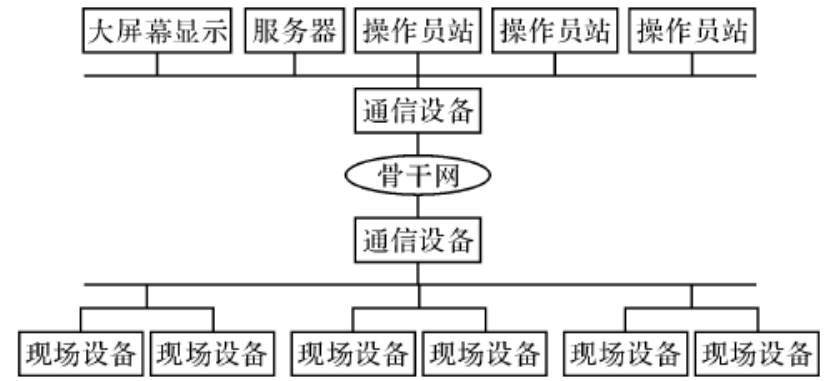

图 2 城市轨道交通综合监控系统平台结构示意图

与此同时，综合监控系统行分层分布式管控机制（数据接入层+数据共享层 + 人机界面/决策层), 解决空间与时间 对调度操作的限制, 让系统具有远程监控、多专业联动功能。而无论是数据接入层 (传感器、自动化仪器仪表等) 还 是数据共享层 (电力监控系统、火灾自动报警系统、信号系统、综合安防系统等)、人机界面/决策层 (控制中心、信 息管理系统）其技术支持需依托统一硬软件平台支撑 ${ }^{\left[{ }^{2]}\right.}$ 。基于共性分析, 可将城市轨道交通综合监控系统平台分为: 硬 件平台、数据管理平台、网络通信平台、系统联动平台。

\section{2 系统硬件平台设计技术}

城市轨道交通综合监控系统硬件平台及其构建是系统嵌入式软件功能有效实现的根本保障, 并与应用系统存在支 撑关系。硬件平台由众多硬件设备构成, 就数据接入层、数据共享层而言, 涉及到的设备与装置主要有数据采集装置、 数据处理装置、电气装置、可编程控制器、闭路电视、售票机、光纤通信装置、电源装置、微处理器智能控制装置等 ${ }^{[3]}$ 。 对此，在城市轨道交通综合监控系统硬件平台设计中，注重设备布局设计、设备连接设计、设备专业化管理设计等。 在设备布局设计中, 需要根据实际情况做好逻辑电路分析工作, 以保证电路布局科学、准确、有效, 避免电路布局不 合理出现短路、断路等故障, 影响设备供电质量。就设备连接设计而言, 以太网技术、现场总线技术等的推广应用为 系统各硬件设备互联互通提供了支持, 为设备运行状态管控奠定了良好通信基础。在设备专业化管理中, 需根据系统 各子系统功能，进行专业设备模块化组装，便于硬件平台与软件平台的连接。

\section{3 数据管理平台设计技术}

在数据管理平台设计中, 为满足城市轨道交通综合监控系统功能需求, 需以 “高可靠性”、“高集成性”、“高有效 性” 等为基本原则。在原则指导下, 科学选择平台建设技术进行平台设计思路实现。从数据管理平台构成来看, 数据 管理平台的可靠、有效、稳定运行，离不开数据管理构件与数据访问通信网络支撑。而数据管理构件则依靠数据库、 内部并行机制、多线索结构等技术支持, 并在 SDE（Software Development Environment, 软件开发环境）进行具体体 现。例如, 通过搭建 Java 开发环境或利用虚拟机, 在数据库中完成相关代码编写、管理与执行, 实现 Jvaa 类构件定 
义 (如自定义函数、数据存储过程等); 运用 XML (eXtensible Markup Language, 可扩展标记语言) 进行相关构件制 作 (如数据恢复、数据存储等)。由于 XML 不受操作系统、编程语言限制, 可有效提升数据访问能力, 满足数据跨系统 交换与传输需求, 提升子系统间、子系统与控制中心间信息共享水平。又如, 应用分布、分区、分层技术, 构建分区 视图构建可将数据根据应用系统需求分布到相应服务器中, 从而满足城市轨道交通综合监控系统数据源一致性、数据 管理集成性、数据利用多样性需求。

\section{4 网络通信平台设计技术}

如何有效实现跨平台数据库共享是城市轨道交通综合监控系统建设过程中关注 的重点问题。而要想解决这一问题, 其网络通信平台建设, 需不同于面向具体单项 应用的传统监控系统网络通信平台，而应是面向对象机制的集中式平台。对此，可 利用中间件技术进行平台设计。中间件（如图 3) 是位于操作系统与应用程序之间 的通信服务软件, 支持分布式计算与标准网络协议与标准数据接口, 能够屏蔽操作 系统复杂性, 能够为异构系统提供透明的应用交互、服务交互。

城市轨道交通综合监控系统为满足数据共享需求, 能够从现有信息系统中有效 提取信息并将其科学发送。在网络通信平台设计与建设过程中, 应善于利用信息源 接口技术、信息标准技术。例如, 数据采集、数据处理、数据传输的分散处理单元 上端配置冗余网络接口, 在下端配置集成系统网络的统一接口, 从而能够将不同位

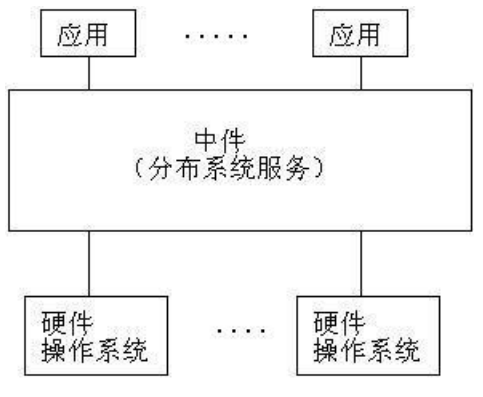

图 3 中间件 置、不同类型、不同来源数据依据既定规则处理, 按照规范格式存储于发送。

\section{5 系统联动平台设计技术}

系统联动平台是基于上述平台组合下形成的高层次平台。在该平台设计与建设过程中，可利用智能组态技术实现多 专业系统各类数据组态接入, 利用数据挖掘技术、信息融合技术对多来源数据、多类型数据进行智能分析, 探寻数据所 蕴含的规律, 从而进行行为预测, 为业务决策提供奠定良好信息基础。与此同时, 系统联动平台建设过程中, 可利用视 频数据集成技术进行视频智能分析, 通过数据可视化显示, 便于工作人员及时了解城市轨道交通情况。此外, 为保证数 据共享安全, 依托数据安全技术 (组织安全技术、存储安全技术、传输安全技术等) 进行多层次、全方位防护。

\section{2. $6 \mathrm{SDH}$ 传输网方案}

在城市轨道交通综合监控系统平台中, SDH 传输网络方案具有以下方面的应用优势。一, 具有统一的网络节点接口, 同时其信息结构等级趋向标准化, 并且其传输速度更快, 信息加载的方式更安全。二, 基于 SDH 技术的应用, 其再次应 用的过程更加简单, 并且能够兼容其他类型的系统, 例如 PHD 系统。实践应用中, SDH 传输网络方案的应用, 使得网络调 度管理的过程更加方便灵活, 并且能够对不同方向的数据流进行分析和整理。三, 该技术具有强大的网络管理功能, 并 且其自愈技术比较完善, 网络保护功能强大。然而, 实践过程中, SDH 网络也存在一些缺点, 具体表现如下, 不能为业务 提供宽带支持, 无法满足各种控制系统的联网需求, 倘若进行联网设计, 需要另行购进专业化的通信处理设备。

视频图像的采集多以点对点的形式存在, 并且以固定接入的数字压缩编码方式进行数据传输, 因此数据采集成本 较大, 影响技术的广泛应用。并且对特殊的数据信息需要进行光纤通信方式设计, 其价格相对较高, 而且该技术也无 法连接广播系统 8 20kHz 的音频接口, 具有应用局限性。

\section{结论}

总而言之, 城市轨道交通综合监控系统平台设计基本功能需求的实现离不开先进科学技术的支撑。这就需要相关 工作人员能够明确认知城市轨道交通综合监控系统建设要求, 立足其平台设计基本功能需求, 进行设计基本功能实现 技术探究, 通信息标准技术、数据挖掘技术、系统集成技术、信息安全防护技术等科学运用, 进行理想城市轨道交通 综合监控系统科学构建, 为城市现代化、智能化建设奠定良好系统管控基础。

\section{[参考文献]}

[1] 李明,何治达. 城市轨道交通综合监控系统云平台架构设计方案比较 [J]. 城市轨道交通研究, 2018, 21 (09) : 64-66.

[2] 张志学, 刘佩, 张长开, 等. 城市轨道交通综合监控人机交互系统技术要点 $[\mathrm{J}]$. 城市轨道交通研 究, 2019, 22(11) : 108-112.

[3] 张劯阳, 吴倩, 刘浩然, 等. 基于系统互操作性的城市轨道交通综合监控系统测试方法与评估体系 [J]. 城市公共交 通, 2019(05): 31-34. 
作者简介: 间小楼 $(1982-)$, 工程师, 本科。 


\title{
英美城镇化中后期发展进程对重庆转型发展的启示
}

徐锦影 付 帅

重庆市规划设计研究院，重庆渝北 404000

[摘要]城镇化水平是一个国家和地区经济、社会、文化、科技水平的主要标志，也是衡量国家和地区社会组织程度和管理水 平的重要标志。通过分析英国和美国从城镇化水平超 $60 \%$ 后的发展特征、发展模式及动力、中后期城市空间扩展特征、中后 期城市空间扩展特征、城乡居民需求等方面将两个国家城镇化发展水平达到 $60 \%$ 以后的特征进行总结，预先判断重庆城镇化 发展的重点方向及策略, 以此指导转型期重庆健康城镇化的具体实践，以期推动中国西部城镇化模式的创新。

[关键词]城镇化; 城镇化水平; $60 \%$; 转型发展; 重庆

DOI：10.33142/sca.v3i1.1533 中图分类号：D25;F299.21 文献标识码：A

\section{The Enlightenment of the Development Process of the Middle and Later Stage of British and American Urbanization on Chongqing's Transformation and Development}

\author{
XU Jinhao, FU Shuai
}

Chongqing Planning \& Design Institute, Yubei, Chongqing, 404000, China

\begin{abstract}
The level of urbanization is main symbol of the level of economy, society, culture and science and technology of a country and region. It is also an important symbol to measure the level of social organization and the level of management in a country or region. Based on the analysis of the development characteristics, development mode and power, urban space expansion characteristics in the middle and later period, and the demand of urban and rural residents of the United Kingdom and the United States after the urbanization level exceeds $60 \%$, this paper summarizes the characteristics of the urbanization development level of the two countries after reaching $60 \%$, and prejudges the key direction and strategy of the urbanization development of Chongqing, so as to guide the specific practice of healthy urbanization of Chongqing in the transition period to promote the innovation of urbanization mode in Western China.
\end{abstract}

Keywords: urbanization; urbanization level; 60\%; transformation and development; Chongqing

1 引言

城镇化是经济社会发展的必然趋势, 是现代化水平和衡量国家和地区社会组织程度及管理水平的重要标志。我国 城镇化已进入加速发展阶段, 我国现代化建设中的重要任务即是协调和管理好城镇化。直辖以来, 重庆经济和城镇化 率均得到飞速发展, 2018 年重庆全市常住人口 3102 万人, 常住人口城镇化率 $65.5 \%$, 较上年提升 1.4 个百分点, 高于 全国平均水平 (59.6\%) 约 5.7 个百分点, 人口集聚能力明显提升。伴随着全市经济的快速发展, 常住人口规模和城镇 化率保持较快增长态势, 常住人口较上年增加 27 万人，增量明显高于去年同期水平 (25. 2 万人), 城镇人口较上年增 加 61 万人, 增量明显高于去年同期水平 ( 55.4 万人)。重庆城镇化水平虽然在西部有较强的优势, 但和其他直辖市相 比差距不小，北京、上海、天津城镇化发展均超过 $70 \%$ 。重庆处于加速发展期的中后期, 是推进城镇化的关键时期。在 推进城镇化中, 既要遵循城镇化发展的规律, 借鉴国际国内推进城镇化的有益做法, 又要符合重庆实际, 适应重庆工 业化和经济社会发展水平, 走出一条符合重庆实际的新型城镇化道路。

\section{2 国外城镇化进程及其经验}

\section{1 英国}

2.1.1 城镇化水平超 60\%后发展速度及城镇化 60\%-80\%经历的时长

1865 年, 英国城镇化率达到 60\%, 是世界上最早启动城镇化的国家。1 920 年达到 $80 \%$, 经历了 55 年平稳上升期。 而后 50 年间，基本保持在 $80 \%$ 上下。1970 至 1980 年之间，十年间从 $80 \%$ 上升到 $90 \%$, 非常快速。至今，一直保持在 $90 \%$ 左右。

2.1 .2 城镇化动力及发展模式

（1）城市化的起始。英国城市化与工业革命同步，始于 18 世纪 60 年代。经历了圈地运动（长达几个世纪）、农 